\title{
UNIVERSITYOF
}

FORWARD

THINKING

WESTMINSTER用

WestminsterResearch

http://www.westminster.ac.uk/westminsterresearch

Provision, protection or participation? Approaches to regulating children's television in Arab countries

Sakr, N.

This is a copy of the accepted author manuscript of the following article: Sakr, N. 2017. Provision, protection or participation? Approaches to regulating children's television in Arab countries. Media International Australia doi:10.1177/1329878X17693933.

The final definitive version is available from the publisher Sage at:

https://dx.doi.org/10.1177/1329878X17693933

(C) The Author(s) 2017

The WestminsterResearch online digital archive at the University of Westminster aims to make the research output of the University available to a wider audience. Copyright and Moral Rights remain with the authors and/or copyright owners.

Whilst further distribution of specific materials from within this archive is forbidden, you may freely distribute the URL of WestminsterResearch: ((http://westminsterresearch.wmin.ac.uk/).

In case of abuse or copyright appearing without permission e-mail repository@westminster.ac.uk 


\section{Provision, protection or participation? Approaches to regulating children's television in Arab countries}

Locally-made children's television was a late arrival to the regional landscape of panArab satellite television channels that mushroomed in the 1990s and 2000s. Arab governments held on to their terrestrial broadcasting monopolies well into the $2000 \mathrm{~s}$ and those in the more populous states, such as Egypt, Syria and Morocco, provided some local content for children alongside imports. On Arab satellite channels, however, non-Arab imports dominated the small amounts of children's content provided. Even ART, a pay-TV network privately owned by a Saudi magnate, who created it to offer an Arab-Islamic alternative to Western programmes, rebroadcast Cartoon Network/TNT, created by Ted Turner in 1992, as its earliest child-friendly option (Sakr, 2005: 42). Spacetoon Arabic, a Dubai-based free-to-air satellite channel founded in 2000 as an outgrowth of the dubbing and distribution activities of its Syrian owner, majored on animation from Japan and the US, while MBC Group, the leading Saudi-owned pan-Arab network, used MBC3, the children's channel it launched in 2004, as an outlet for material acquired through bulk deals with Hollywood studios (Sakr 2007: 130). Qatar inaugurated Al-Jazeera Children's Channel (JCC) in 2005 with the much-publicised aim of producing 40 per cent of its own content but barely six years later its new management reverted to heavy reliance on material from Disney and the $\mathrm{BBC}$, perceiving this as essential to rebuild audiences for the channel it rebranded as Jeem (Sakr and Steemers, 2106: 246-47).

Despite periodic growth spurts in provision of Arab channels targeted at children, most of them financed from Jordan and the Gulf, rules and rationales governing production and acquisition of children's content in the region have remained far from transparent. The longer opaqueness continues the more policy and regulation blur into each other, since regulation, besides giving effect to policy, also predates it in the sense that interest groups seeking to influence the policy-making process benefit from resource allocations that previous regulation has brought about through existing market structures (Hills 2002: 12). There is public rhetoric about protecting children from material that allegedly breaches 'cultural boundaries and values' and the need to provide programmes that revere a perceived 'Arab-Islamic' heritage and preserve literary forms of the Arabic language. But Arab production companies that are eager to make screen content for children were still complaining well into the 2010 s that the 
incentives provided for this purpose in other countries are lacking in their part of the world (Awan and Steemers, 2017: 35-36). Against that background, this article compares approaches articulated by media regulators, television networks and content producers regarding how best to achieve beneficial screen content for Arabic-speaking children. It does so from a critical political economy perspective, which recognises that rule-making structures are key to shaping markets and capital flows and thus the cultural output that makes a material contribution to reproducing the social and political order (Sakr 2012: 226).

\section{Bases for comparison}

Various classifications can offer a basis for comparing between approaches to regulating children's television. One of the clearest potential distinctions is between 'positive' and 'negative' regulation. While the latter seeks to protect children from 'violent, sexual or over-commercialized content', the former - starting from the assumption that television can be beneficial to children - mandates publicly-owned organizations to entertain, inform and educate them through relevant locally produced material and also, in some instances, makes broadcast licences conditional on fulfilment of production quotas or offers subsidies and tax breaks to stimulate production (Steemers and D'Arma 2012: 78-79). Judged in light of the three principles underlying the UN Convention on the Rights of the Child (CRC), namely provision, participation and protection, positive regulation could be seen to privilege the principle of provision while negative regulation does the same for protection. However, as widely argued, the three principles have to be regarded as indivisible and interdependent, each being a pre-requisite for the other (Verhellen 2015: 50). This applies equally to Article 17 of the CRC, which deals with children's access to socially and culturally beneficial media content, in the sense that children need appropriate information and insights if they are to participate effectively and protect themselves from harm. At the same time, for information to be truly beneficial, its production depends on children's participation and protection in media output in ways that are far removed from the 'implicit adultism' currently prevailing in, for example, Internet governance (Livingstone 2016).

An alternative classification of regulation distinguishes between self-regulation and legislation, the former gaining ground as part of a perceived shift from government to 
'governance', whereby the state steers policy making via public-private partnerships, voluntary agreements and other 'soft', informal, or consensual mechanisms (losifidis 2016: 21). Article 17 of the CRC was drafted in a way that sits quite comfortably with the idea of a state that 'typically manages and orchestrates' (Iosifidis 2016: 21). Although its first sentence requires the state to 'ensure' that 'the child has access to information and material from a diversity of national and international sources, especially those aimed at the promotion of his or her social, spiritual and moral wellbeing and physical and mental health', the remaining clauses merely call on the state to 'encourage' things to happen. This includes encouraging: international cooperation in producing and sharing children's content; publication and distribution of children's books; and mass media to have regard for minority languages. The final clause commits the state to 'encourage the development of appropriate guidelines for the protection of the child from information and material injurious to his or her well-being, bearing in mind the provisions of Articles 13 and 18'.

As has been pointed out (Sacino 2012: 30-31), the wording of the last clause, especially the vague phrase 'bearing in mind', conveniently sidesteps difficult questions. Although, given the mention of Article 13 on freedom of expression, the clause does not condone state censorship, its reference to 'develop[ing] guidelines' opens the field to unspecified non-state bodies without indicating any likely source of particular expertise. Moreover, since Article 18 gives parents primary responsibility for their children's well-being, the 'guidelines' mentioned in Article 17 seem to imply that parents should control their children's media use while the state, despite its 'enormous power' to control mass media activity, is allowed to play a 'backseat role' (Sacino 2012: 31).

However, in pondering the degrees of interventionism envisaged in Article 17, it should not be assumed that something called 'non-regulation' lies at the opposite end of the spectrum from state-enforceable regulation. If an institution with the power to regulate decides not to do so, that decision can illuminate power relations just as much as a decision to regulate (Lacey 1993: 96). Similarly, specialists in many fields have suggested that 'de-regulation' is more accurately termed 're-regulation', since removal of one set of rules serving certain sets of interests may simply result in other rules with benefits for different interest groups. Media governance in the Arab region has anyway been described as a complex, multi-layered matrix of modalities that 
enables media operators and states to accommodate their mutual priorities in a way that appears to avoid direct intervention but succeeds in constraining any challenge to local and national politics (Khalil 2015: 28-30). Seen in light of the above observations, a failure to regulate in favour of beneficial and appropriate media for children is a political decision, not an innocent abstention from intervention.

The significance of such a failure becomes even more apparent if regulation's potential to promote children's participation is taken into account. The Committee on the Rights of the Child, the treaty body that monitors compliance with CRC, lists Article 17 as one of five articles in the Convention in which children's 'participation rights' are 'set out' (Committee on the Rights of the Child 2014: 1), not least because of the link between the right to access information and the right to be heard. Children's right to be informed includes hearing other children's voices, or receiving content that other children have participated in producing (Hammarberg 1997: 250; 260). But the declared interdependence between provision, participation and protection also implies that children should participate in devising ways of bringing about beneficial media provision and protection from harmful content. It is widely recognised that this presents a challenge, even in the era of children's parliaments and councils, because formulae for involving children are predominantly adult-led or simply mimic adult equivalents. As Nigel Thomas has written (2007: 207), despite the extent to which political decision-making affects the lives of children and young people, 'there is very little sign of children and young people really participating in the processes that actually produce important political decisions, or in contributing to defining the terms of policy debate'.

In the following sections, which deal in turn with approaches to regulation adopted by Arab regulators, broadcasters and content producers, the above considerations provide a framework for selection and analysis of data and ultimately for reaching a conclusion. Data were collected from official documents and speeches, the trade press and fieldwork interviews conducted as part of a research project on screen media for Arabic-speaking children funded by the UK's Arts \& Humanities Research Council (AHRC). ${ }^{1}$

\section{Regulatory agencies: limited visions of protection}

\footnotetext{
${ }^{1}$ Grant number AH/J004545/1.
} 
The absence of transparent rules governing Arab satellite channels operating transnationally has long been a sore point among would-be censors as well as those who wish for regulation in the public interest. A so-called Arab Satellite Charter, proposed by the governments of Egypt and Saudi Arabia in 2008 to enshrine authoritarian controls on editorial content, failed to gain regional endorsement (Sakr 2010: 39-43). Several years later the Tunis-based Arab States Broadcasting Union (ABSU), which primarily serves a majority of government-run broadcasters in the region, characterised the situation as 'a broadcasting space with no regulatory framework', suffering from 'weak content' and a 'risk of chaos and absence of values' (ASBU 2016).

The transnational situation reflects Arab governments' long-standing reluctance to cede powers to non-government operators. In many Arab countries, even those claiming to have a separate regulatory agency for broadcast media, national audiovisual regulation effectively remains an exclusive government prerogative and rules are devised and interpreted to benefit the government of the day. Authorities that are at least nominally separate from ministries ${ }^{2}$ have been created in Algeria, Jordan, Lebanon, Morocco, Tunisia, Saudi Arabia and the United Arab Emirates (UAE). In Algeria and Saudi Arabia, however, the move has not signalled any departure from coercive pro-government interference in media activity. ${ }^{3}$ Four of the other authorities, in contrast, are recognised members of the Mediterranean Network of Regulatory Authorities (MNRA), a forum that also incorporates regulators of European countries with democratic political systems. Created in 1997, the MNRA is one of a number of associations of broadcast regulators that, like the European Platform of Regulatory Authorities (EPRA), established two years earlier, aim to provide a setting for informal exchange of information, frank discussion and best practice. ${ }^{4}$ An equivalent network for francophone authorities, Refram, set up in 2007, counts two Arab bodies, Morocco's Haute autorité de la communication audiovisuelle (HACA) and Lebanon's Conseil national de l'audiovisuel (CNA) among its members.

\footnotetext{
${ }^{2}$ For detail on the powers and responsibilities of some of these see Dabbous-Sensenig 2012: 83-94.

3 International human rights bodies have documented trials and incarceration of journalists and internet users in both countries.

4 EPRA's purpose is worded like this on its webpage at http://www.epra.org/articles/generalinformation-on-epra
} 
Promoting protection of children has been the common focus in MNRA and EPRA exchanges with Arab regulators. Lebanon's CNA, formed in the 1990s under a law rationalising the country's broadcasting after its 15-year civil war, is partly appointed by the Ministry of Information and its powers are limited to advising the government about issuing broadcast licences. When the European Union supported a conference in Beirut in May 2016 to discuss reforms that would make the CNA independent, one of the event's three themes, alongside political pluralism and gender stereotyping, was the 'protection of minors in a converging environment', with participation of regulators representing Italy, Croatia and EPRA (Med-Media EU 2016).

Two MNRA declarations issued in 2008 and 2009 have a similar focus. Agreed in the Moroccan city of Marrakesh, the MNRA's 2008 'Declaration on Audiovisual Content Regulation' commits signatories to respect human dignity, protect the rule of law, ensure accuracy of information and respect plurality of opinions. A large part of the short document deals explicitly with 'Protection of Children and Adolescents', whereby MRNA members declare their intention to 'ensure compliance' with three specific articles of the UN's CRC (MNRA 2008: Art. 3). They undertake to uphold Article 34, protecting children from 'all forms of sexual exploitation and sexual abuse', by blocking access to pornographic or 'gratuitously' violent programming by means of a 'locking mechanism'. They commit to Article 17, which the Declaration reduces to its final clause, saying that the article's 'purpose' is to protect children from images which may be harmful to their well-being. Here MRNA members state that they 'intend to ensure' that service providers warn the public about inappropriate content and refrain from programmes that 'trivialise' consumption of tobacco, alcohol or drugs or incite children to behave in a violent manner. Thirdly, in respect of the CRC's Article 29, signatories pledge to 'encourage' providers of audiovisual services to 'educate children to have respect for human rights and tolerance'.

Protectiveness carries through to the 'Declaration of Intent Concerning the Protection of Young Publics and the Fight against the Violence in the Media', issued in 2009. According to its own wording, this document resulted from concern among MRNA members about 'insufficient control on satellite broadcasting' and the emergence of 'channels intended for babies'. It recommends four measures, including identifiers for programmes aimed at young audiences; information for parents about the dangers of television for under-threes; creation of a media literacy alliance; and better 
cooperation among members, through training and sharing the names of experts in child protection.

For regulatory authorities like those of Jordan and Lebanon, which can only advise on broadcast licensing instead of issuing licences themselves, the discourse of protecting children tends to align with that of vaguely-worded censorship, as demonstrated in Jordan's most recent report to the Committee on the Rights of the Child. Stating that 'one goal' of Jordan's Press and Publications Department is to 'shield children from exposure to inappropriate information', the report subsumed 'abuse of children's rights' into any 'offence' against 'national religious norms, values and traditions' (CRC 2013: 18). When it comes to other types of protection, however, such as codes adopted in some European countries against advertising for foods that are high in fat, salt and sugar (HFSS), the Jordan Media Commission, created through a merger of the Press and Publications Department and Audiovisual Commission in 2014, has no published mandate (UNESCO 2105: 125). In contrast, Tunisia's Haute autorité indépendante de la communication audiovisuelle (HAICA), which issued specifications for licensing and content regulation of private television stations in 2014, has rules banning children from appearing in commercial advertisements unless the product is aimed at them and requiring that food advertising should warn against ill-effects of excessive consumption (Article 19 2014: 12-13).

There are also forms of protection geared to facilitating children's participation in television programmes. Within the UAE, the Abu Dhabi Media Zone Authority (MZA), set up to help establish a media hub in the emirate and linked by personnel to the UAE's federal National Media Council, makes protection of children the number one item in its Content Code but also elaborates on it in a special set of guidelines devised for anyone working in the Abu Dhabi Media Free Zone when dealing with under-eighteens. The Content Code calls for warnings before any abrupt shift to adult content and bans various kinds of material, including content that could result in children consuming harmful substances. Its Rule 1.3 relates to children who are involved in content, insisting that, where possible, children themselves should give informed consent and that they must not be caused any distress or anxiety (MZA nd: 8). The MZA's Guidelines on Safeguarding Children, issued in November 2011, refer to 'worldwide best practice' in the field and, while setting out seven pages of 
recommendations about informed consent, health and safety, chaperones and so on, urge bodies working in the Media Zone to develop their own more detailed internal guidelines to deal with the issues.

As host to the production of various children's programmes, the MZA had good reason to think of children's participation as well as their protection. But UAE media regulation does not yet extend to requiring broadcasters to provide children's programming as it does in Morocco and Lebanon. Under Morocco's Audiovisual Communication Law enacted in 2004, both the former state broadcaster, RTM, and another publicly owned company, $2 \mathrm{M}$, were given the status of public service entities with an obligation (under Articles 3 and 10) to carry at least ten hours per week of children's programmes, which (under Article 15) is not to be interrupted by advertising (Zaid 2009: 128-130). A study of mandatory daily current affairs programming screened by the two channels showed that these have also involved children's participation as programme guests (Zaid 2009: 168). In Lebanon, in contrast, programming quotas were written only into the Guidebook for Operating Conditions, not the law. In this way a quota of 146 hours per year was set for locallymade programmes aimed at children and youth (Dabbous-Sensenig 2003: 132) but was not enforced (Dabbous-Sensenig 2012: 91).

\section{Broadcasters: censorship for business reasons}

Although not directly subject to national regulation, executives of transnational Arab channels aimed at children, such Spacetoon, MBC3 and Jeem, share national regulators' predominant preoccupation with shielding children from certain types of content. In the absence of a regional standard, they practice voluntary censorship, which varies from channel to channel but is primarily dictated by cultural norms prevailing in the region's most lucrative markets for advertising revenue, namely Saudi Arabia, Qatar and the UAE. Thus Nadine Hassan, MBC3's channel manager for its first seven years, confirmed in 2010 that her channel 'cut many things' because 'late watching' is 'rampant' in Gulf countries, 'where kids stay up to midnight' and 'mothers say their four-year-olds are watching TV at 9pm' (Hassan 2010). In the fasting month of Ramadan, she said, 'we are a hundred times more careful about censorship'. Because, according to Hassan, 'parents don't watch MBC3 with their kids', 'content suitability is a massive issue'; the volume of imported 
material means that the channel has 'to do censorship that cuts stuff away', such as dating for example, which is 'not accepted' (Hassan 2010).

Some may question whether content that shows dating counts as what the CRC's Article 17 calls 'material injurious' to a child's well-being. However, the same article's oblique reference to parental responsibility implies that definitions of injury and wellbeing are for parents to decide. Amer Bitar, who worked for a long time with Spacetoon, says (2013) he heard from 'from lots of people' that parents 'don't want to have their kids introduced to [the idea of] a boyfriend or girlfriend' as they would on a western channel such as Nickelodeon. He believes (2013) that foreign suppliers of programmes to Arab channels are 'OK with censorship' because they are 'cautious about anything that may affect the Saudi market'. Recalling losses incurred when Saudi Arabia's highest religious authority banned the Pokemon computer game and cards in 2001, on the grounds that it 'promotes Zionism and involves gambling' (BBC 2001), leaving retailers with unsold merchandise, Bitar pointed out (2013) that, even allowing for the cost of making editorial cuts, it still makes more business sense for Arab broadcasters to show imported content than to create their own because the 'minimum cost for any animation of 26 episodes is not less than $\$ 5$ million and the market cannot monetize that amount'. Fayez Al-Sabbagh, head of Spacetoon Media Group, confirmed that 'our [imported] animation, between the dubbing and censorship, costs me [an extra] \$140-200 per episode'; but, he says, 'it's cheaper than making new content' (Sabbagh 2013).

Jeem TV in Qatar has a Compliance Department that vets all content for suitability and, according to an editor working in the department, 'many, many points are rejected' from imported content, including any extensive references to Christmas or Easter or any reference at all to Valentine's Day, 'bad behaviour', boy-girl love relationships, alcohol, swear words, and incidents of rebelling against family or the social structure (JCC 2013). Even though editorial self-regulation is such a prime concern, however, Arab-owned transnational children's channels have no forum for discussing this or other issues apart from ASBU, which, by virtue of the number of government-run broadcasters in Arab states, is dominated by government ministers. Addressing a conference attended by other channel executives, Nadine Hassan observed (2010) that this was the 'first time I have been in a room with the competitors to our channel ...We need to do this more often'. At the same event she 
noted the absence of regional regulation, saying 'we can't do it individually, as independents'.

Indeed, transnational channel managers have, on occasion, expressed a wish for channels to be subject to regulation. Malika Alouane, programme manager at JCC before a sweeping change of management there in 2011, said people in the region needed to understand the difference between regulation and censorship (2010: 34). Referring to practices in Europe, she said Arab countries should put in place regulation to provide safe content for the 'younger age groups', who 'are quite used to seeing channels promote bad content - in terms of junk food or in terms of adverts' and have started 'regarding it as normal' (2010: 34-35). Broadcasters have rarely called, however, for positive regulation that would require more local production of children's programming, or material that is more participatory. Daoud Kuttab, community media campaigner and founder of a Palestinian television channel and Jordanian radio station, is unusual in urging 'must-carry' obligations as a licensing condition for private broadcasters, proposing that they might be required to devote a fifth of programming to youth issues or issues of interest to 'marginalised communities' (UNESCO 2015: 106).

As for facilitating children's participation, it can be noted that MBC3's flagship inhouse production, a reality series called Eish Safari, that has run every year since 2005 and selects a few children from thousands who apply, has been shot in locations beyond its UAE base, where the UAE guidelines discussed above may or may not be considered relevant, from South Africa, Australia and the US to Turkey, Malaysia and Morocco. There are also logistical issues beyond the regulatory ones, which increase the challenge of involving children in television content in Gulf countries. These include the need for separate green rooms for boys and girls or having to cater for whole families accompanying children as chaperones, to having children fail to turn up because of last minute family objections (Steemers 2013).

\section{Independent content producers: a different set of concerns}

When content producers' comments about regulation are compared with those of regulators and broadcasters, a rather different set of preoccupations emerges. Although the number of children's channels in Arabic had reached ten or more by 2014 (Cartoon Network 2014), stimuli aimed at actual provision of local material to fill 
these channels remained limited by financial and political considerations. Financially, as evidenced by Spacetoon's calculations, it was more profitable to import than create. Politically, the conflation of 'protecting' children with avoiding content that might be deemed to challenge national 'traditions' or 'values' limited the scope for innovation. Such constraints could be inferred from the words of Antoine Saad, head of the Lebanese channel Télé Lumière, when launching a new satellite channel 'Nourkids', in March 2015. The channel, he said, 'seeks to instill children and adolescents with ethics and values (sic), and drive them away from delinquency and evil' (Noursat TV 2015).

In contrast, on the rare occasions when Arab producers of children's content sanpeak in public about regulation, their aspirations have more to do with protection of intellectual property (IP), subsidies and industry incentives, and the raising of professional standards. Samer Hamarneh, of Amman-based Rubicon Holding Group, which has studios in the US and Philippines as well as Jordan and Dubai and has had content shown on MBC3, Cartoon Network Arabia and elsewhere, told a business audience in Dubai in 2013: 'Governments here need to protect IP. My IP is not protected; you will see fakes everywhere. And on top of that there are no tax exemptions or industry incentives to protect us' (Hamarneh 2013a). Hamarneh says (2013b) he has always recommended what he called the 'Malaysian model', whereby government subsidies help to create local animation that is exported, in preference to the Filipino model where, he says, outsourcing is 'kill[ing]' the country's creative industry in animation.

Nathalie Habib of Blink Studios in Dubai told an academic gathering in London in 2015 that it was a challenge to find local scriptwriters who could be helped to write to the standards required for international distribution, but not an impossible one, as demonstrated by Blink's contribution to the second season of Driver Dan's Story Train, an Arab-British co-production shown on CBeebies (Habib 2015). The problem, she said, was that potential financiers were too ready to look abroad for expertise and this produced scripts with foreign allusions (to 'Christmas, Santa Claus, Halloween, witches, pumpkins' and so on) that have no place in local culture. The region's wealth, she said, was not translated into 'producing for our kids'. 'In the rest of the world', in Habib's words (2013), toy companies and distributors talk about 
licensing IP for the 'next show', but 'here we don't have that because broadcasters buy off the shelf'. Whereas other countries recognise that society needs to support building content for children, through subsidies and tax credits, Arab governments have yet to 'realise that this is an industry to put money into' (Habib 2013).

Meanwhile, investment also depends on regulatory structures that guarantee contractual security and financial predictability. These enable independent producers to, for example, fund their own demos or whole projects first, without relying solely on commissions from state institutions. According to Egyptian animators (Sayfo 2016: 111), upheaval in Egypt after 2011 saw budget cuts at the state broadcaster exacerbated by Gulf buyers' turning to Indian animators in place of Egyptian ones, fearing they might lose deposits paid in Egypt. Coming on top of an already relatively precarious situation in which a lack of professional training in 3D animation meant Egyptian companies either had to train people themselves or hire self-taught animators, regulatory uncertainty caused a setback to the Egyptian animation industry (Sayfo 2016:111).

\section{Conclusion}

It is obvious from the comments of independent content producers quoted here that regulating media for children's benefit is potentially much more multi-faceted than the predominantly negative, so-called protective version articulated by both the region's regulatory agencies and broadcasters. But it is also evident that the discourse and mechanisms of protection, embedded as they are within media laws that are said to defend cultural norms and traditions but are designed first and foremost to shield governments from public scrutiny, have become entrenched to the point of being virtually beyond question. That is to say: existing regulation and structures serve to determine policy (Hills 2002: 12) as well as investment. As indicated by the remarks of Alouane, Hamarneh and Habib, any attempt to extend or diversify the meaning of media regulation in this context starts at a severe disadvantage. Controls on television advertising for children have so far been adopted only on the fringes of Arab broadcast regulation. Obligations to carry specified quotas of children's content or locally-originated content for children, even where these nominally exist, have not been imposed on private channels, least of all those that operate transnationally. As demonstrated by the declarations on protection signed jointly by Arab and European 
regulatory agencies in the MNRA, even voluntary initiatives relating to regulation have been a top-down process with minimal participation of Arab civil society and certainly none from the region's children.

The evidence also shows that it may sometimes be a mistake to think in terms of a 'positive vs negative' binary where regulation is concerned. When locally-generated content is motivated by a concern to protect children from 'delinquency and evil', as in the case of NourKids, or material that is felt to be culturally inappropriate, as in the case of Jeem TV, it is hard to classify its provision as representing a positive or negative regulatory impulse. The Abu Dhabi Media Zone Authority set an interesting example in encouraging its partners to develop their own internal guidelines for dealing with under-18s. Yet self-regulation in relation to Arab children's media is mostly displayed in broadcast channels' self-interested self-censorship, reflecting the dominant regional consensus around a narrow interpretation of 'protection'. The weight of this consensus seems to stand in the way of alternative, wider-ranging approaches to regulation that would stimulate provision and participation.

\section{References}

Alouane M (2010) Interview. The Channel 2: 34-35.

Article 19 (2014) Tunisia: Specifications for Licensing and Content Regulation of Private TV Stations. London: Article 19

ASBU (2016) Commentary on 2015 Arab satellite broadcasting report. Majallat alItha'at al-'arabiya [Arab Broadcast Review] II-2-16. Summarised translation at http://www.asbu.net/article1.php?artid=1457\&lang=en

Awan F and Steemers J (2017) Arab and Western perspectives on childhood and children's media provision. In: Sakr N and Steemers J (eds) Children's TV and Digital Media in the Arab World: Childhood, Screen Culture and Education. London: I B Tauris, pp. 1-19.

BBC (2001) Saudi Arabia bans Pokemon. 26 March. http://news.bbc.co.uk/1/hi/world/middle east/1243307.stm

Bitar A (2013) Author's interview. By Skype, 16 November.

Cartoon Network (2014) Ipsos Kids Telemetry Study: Saudi Arabia Kids 7-14. Dubai: Cartoon Network, March-April. 
Committee on the Rights of the Child (2013) Consideration of Reports submitted by States parties under article 44 of the Convention: Jordan (CRC/C/JOR/4-5). Geneva: United Nations, 1 March.

Committee on the Rights of the Child (2014) Working Methods for the Participation of Children in the Reporting Process of the Committee on the Rights of the Child (CRC/C/66/2). Geneva: UN, 16 October.

Dabbous-Sensenig D (2003) Ending the war? The Lebanese Broadcasting Act of 1994. PhD thesis, Sheffield Hallam University, UK.

Dabbous-Sensenig D (2012) Arab public broadcasting: Regional synthesis and comparative analysis. In: Consortium IPP-OMEC (ed) Public Service Broadcasting in the MENA Region: Potential for Reform. Paris and Barcelona: Panos Paris Institute and Mediterranean Observatory of Communication, pp. 37-197.

Habib N (2013) Remarks at MYCONTENT Show. Dubai: 19 November.

Habib N (2015) Remarks to conference on 'Comparing Children's Media around the World: Policies, Texts and Audiences. London: University of Westminster, 4 September.

Hamarneh S (2013a) Remarks at MYCONTENT Show. Dubai: 19 November.

Hamarneh S (2013b) Author's interview. Dubai: 19 November.

Hammarberg T (1997) Children, the UN Convention and the media. International Journal of Children's Rights 5 (2): 243-261

Hassan N (2010) Remarks to conference on ‘Children's TV in the Arab World. London: University of Westminster, 4 June.

Hills J (2002) The Struggle for Control of Global Communication. Urbana: University of Illinois Press.

Iosifidis P (2016) Globalisation and the Re-emergence of the Regulatory State. In: Flew T, Iosifidis P and Steemers J (eds) Global Media and National Policies: The Return of the State. Basingstoke: Palgrave Macmillan, pp.16-31.

JCC (2013) Author's interview with Compliance Department staff. Doha: 25 November.

Khalil J. F (2015) Modalities of media governance in the Arab world. In: Della Ratta D, Sakr N and Skovgaard-Petersen J (eds) Arab Media Moguls, London: I B Tauris 2015, pp. 13-30.

Lacey N (1993) 'Theory into practice?' Pornography and the public/private dichotomy. Journal of Law and Society 20(1): 93-113.

Livingstone S (2016) Contribution to plenary panel on Communication Rights. Leicester: Annual conference of International Association for Media and Communication Research, 29 July. 
MNRA (2008) Declaration of the Mediterranean Network of Regulatory Authorities on Audiovisual Content Regulation.

http://www.rirm.org/en/document?id=25\&id document=143

MNRA (2009) Declaration of Intent Concerning the Protection of Young Publics and the Fight Against the Violence in the Media.

http://www.rirm.org/en/document?id=25\&id document=174

MZA (nd) Media Zone Authority-Abu Dhabi Content Code. Abu Dhabi: Media Zone Authority.

MZA (2011) Guidelines on Safeguarding Children. Abu Dhabi: Media Zone Authority.

Noursat TV (2015) Press release: 'NourKids', the children's channel, a new satellite.

Beirut: 23 March. http://www.noursat.tv/en/news-details.php?id=12889

Sabbagh F (2013) Author's interview. Dubai: 20 November.

Sacino S W (2012) Article 17: Access to a Diversity of Mass Media Sources. Leiden: Martinus Nijhoff.

Sakr N (2005) Channels of interaction: The role of Gulf-owned media firms in globalisation. In: Dresch P and Piscatori J (eds) Monarchies and Nations:

Globalisation and Identity in the Arab States of the Gulf. London: I B Tauris, pp.3451.

Sakr N (2010) News, transparency and the effectiveness of reporting from inside Arab dictatorships. International Communication Gazette 72 (1): 35-50.

Sakr N (2012) Placing political economy in relation to cultural studies: Reflections on the case of cinema in Saudi Arabia. In: Sabry T (ed) Arab Cultural Studies: Mapping the Field, London: I B Tauris, pp. 214-233.

Sakr N and Steemers J (2016) Coproducing content for pan-Arab children's TV: State, business, and the workplace. In: Banks M, Conor B and Mayer V (eds) Production Studies: The Sequel! New York and London: Routledge, pp. 238-250

Sayfo O (2016) Arab animated cartoons: Mediating and negotiating notions of identities. PhD thesis, University of Utrecht, Netherlands.

Steemers J and D'Arma A (2012) Evaluating and regulating the role of public service broadcasters in the children's media ecology: The case of home grown television content. International Journal of Media and Cultural Politics 8(1): 67-85.

Steemers J (2013) Interviews with UK consultants with experience of working in the Gulf. London: 25 February and 13 March. 
Thomas N (2007) Towards a theory of children's participation. International Journal of Children's Rights 15: 199-218

Verhellen E (2015) The Convention on the Rights of the Child: Reflections from a historical, social policy and educational perspective. In: Vandenhole W, Desmet E, Reynaert D, Lembrechts S (eds) The Routledge International Handbook of Children's Rights, London: Routledge, pp. 41-59

UNESCO (2015) Assessment of Media Development in Jordan. Paris: UNESCO.

Zaid B (2009) Public service television policy and national development in Morocco. PhD thesis, University of South Florida, US. 